Journal of Biotechnology and Strategic Health Research

Olgu Sunumu / Case Report

http://dergipark.org.tr/tr/pub/bshr

\title{
Döküntünün Eşlik Ettiği SARS-CoV-2 Enfeksiyonu: Olgu Sunumu
}

\author{
SARS-CoV-2 Infection Associated with Rash: A Case Report
}

(D) $\triangle$ Erkut Etçioğlu¹, (D) Abdülkadir Aydın², (D) Bahar Sevimli Dikicier ${ }^{3}$

\footnotetext{
${ }^{1}$ Sakarya Üniversitesi Tip Fakültesi Aile Hekimliği Anabilim Dalı, Sakarya, Türkiye

${ }^{2}$ Sakarya Üniversitesi Eğitim ve Araştırma Hastanesi Aile Hekimliği, Sakarya, Türkiye

${ }^{3}$ Sakarya Üniversitesi Tip Fakültesi Dermatoloji Anabilim Dalı, Sakarya, Türkiye

ORCID ID: Erkut Etçioğlu 0000-0002-8117-7929, Abdülkadir Aydın 0000-0003-0663-586X,

Bahar Sevimli Dikicier 0000-0002-1912-3946

^Sorumlu Yazar / Corresponding Author: Erkut Etçioğlu, e-posta / e-mail: erkutetcioglu@gmail.com

Geliş Tarihi / Received : 08-05-2020 Kabul Tarihi / Accepted: 13-05-2020 Yayın Tarihi / Online Published: 31-08-2020

Atıf Gösterimi/How to Cite: Etçioğlu E., Aydın A., Sevimli Dikicier B. Döküntünün Eşlik Ettiği SARS-CoV-2 Enfeksiyonu: Olgu Sunumu, J Biotechnol and Strategic Health Res. 2020;4(2):173-177
}

$\ddot{O} z$

Çin'in Hubei eyaletindeki Wuhan kentinde akut solunum yolu hastalıklarına yol açan SARS-CoV-2 olarak adlandırılan bir koronavirüs, 2019'un son aylarında tanımlandı. COVID-19 olarak adlandırılan bu hastalık tüm dünyada hızla yayılması ile Mart 2020 'de pandemi olarak nitelendirildi. Dünya çapında yayılması ve olgu sayısında artışla beraber hastalığın klinik belirtilerinde çeșitlilikler saptanmaya bașlandı. Son günlerde COVID-19 hastalığı geçirenlerde cilt bulgularına dikkat çekilmektedir ve bu tabloya dair önemli bilgiler yayınlanmaktadır. Bu yazıda, cilt bulguları görülen bir COVID-19 olgusu sunmaktayı.

Anahtar COVID-19, Cilt Bulguları, SARS-CoV-2 Enfeksiyonu

Kelimeler

\begin{tabular}{|c|c|}
\hline Abstract & \\
\hline & $\begin{array}{l}\text { A coronavirus called SARS-CoV-2, which caused acute respiratory diseases in Wuhan, China, Hubei province, was identified in the last months } \\
\text { of 2019. This disease, called COVID-19, was described as a pandemic March } 2020 \text { with its rapid spread all over the world. With its worldwide } \\
\text { spread and increase in the number of cases, variations in the clinical manifestations of the disease began to be detected. In recent days, those } \\
\text { who have had COVID-19 disease have drawn attention to their cutaneous manifestations and important information about this situation is }\end{array}$ \\
\hline
\end{tabular}

Keywords COVID-19, Cutaneous Manifestations, SARS-CoV-2 Infection 


\section{GIIRIŞ}

SARS-CoV-2 olarak adlandırılan bir koronavirüs, Çin'in Hubei eyaletindeki Wuhan kentinde akut solunum yolu hastalıklarına neden olan etken olarak 2019'un son aylarında tanımlandı. Neden olduğu hastalığın adı COVID-19 olarak adlandırılan bu virüsün tüm dünyada hızla yayılmasıyla Dünya Sağlık Örgütü (DSÖ) tarafından uluslararası düzeyde endişe verici acil halk sağlığı durumu ilan edildi. Mart 2020'de ise mevcut tablo pandemi olarak nitelendirildi. ${ }^{1}$

COVID-19 hastalığının sık görülen klinik belirtileri arasında; öksürük, nefes darlığı, ateş yüksekliği, yorgunluk, koku ve tat almada değişiklik, bulantı, kusma, ishal ve yaygın kas ağrısı vardır. ${ }^{2}$ Yapılan laboratuvar testlerinden; kan lenfosit sayısı, CRP (C-reaktif protein), ferritin ve D-Dimer düzeyleri hastalığın seyrinin ciddiyeti hakkında bilgi verir. Çekilen Toraks Bilgisayarlı Tomografi (TBT)'de görülen tipik buzlu cam alanları ve pnömonik infiltrasyonların görülmesi tanı koymada yardımcı olmakla birlikte, kesin tan1; orofarinks ve nasofarinksten alınan sürüntü örneğinin gerçek zamanlı polimeraz zincir reaksiyonu (RT-PCR) testinin pozitif çıkması ile konur. Klinik bulgular, laboratuvar testleri ve görüntüleme sonuçları hastalara başlanacak tedavi algortimasını belirler. ${ }^{3}$

Dünya çapında görülen olgu sayısında artışla birlikte hastalığın klinik belirtilerindeki çeşitlilik de ortaya konmaya başlanmış ve COVID-19 hastalığı geçiren kişilerde farklı cilt bulguları görülebildiği belirtilmiştir. ${ }^{4} \mathrm{Bu}$ yazıda, cilt bulguları görülen bir COVID-19 olgusu sunulmuştur.

\section{OLGU SUNUMU}

Otuz altı yaşında nefes darlığı, ateş yüksekliği ve tüm vücutta kaşıntı şikayetleri olan kadın hasta dış merkezden pulmoner tromboembolizm ve ilaç erupsiyonu ön tanılarıyla hastanemize sevk edildi. Hastanın anamnezinden 5 gün önce öksürük ve halsizlik şikayetleri ile başvurduğu diş merkezde çekilen Toraks Bilgisayarlı Tomografisinde COVID-19 hastalığı ile uyumlu bulguların görülmesi üze- rine yatırılarak tedavi verildiği öğrenildi. Kayıtlarından dış merkezde; ilk gün azitromisin 500 miligram (mg) per-oral (po) yoldan yükleme dozu; sonraki 4 gün $250 \mathrm{mg}$ po ve ilk gün hidroksiklorokin $200 \mathrm{mg} 2^{\star 2}$ po yükleme dozu; sonraki 4 gün $2^{\star} 1$ po dozunda idame tedavisi ve enoksaparin sodyum 4000 anti-Xa IU/0.4 ml 2*1 subkutan yoldan 5 gün boyunca uygulandığı görüldü. Hastanın özgeçmişinde ve soygeçmişinde özellik yoktu. Fizik muayenesinde yüzünde ve alt ekstremitelerde yaygın yerleşimli, eritemli, keskin sınırlı, birbir-leriyle birleşme eğiliminde makül ve papüller izlendi. (Resim-1) Gövdede ve mukozalarda bulgu gözlenmedi. Döküntülerin bir önceki dış merkezde yattığı dönemin 3. gününde başladığı öğrenildi.
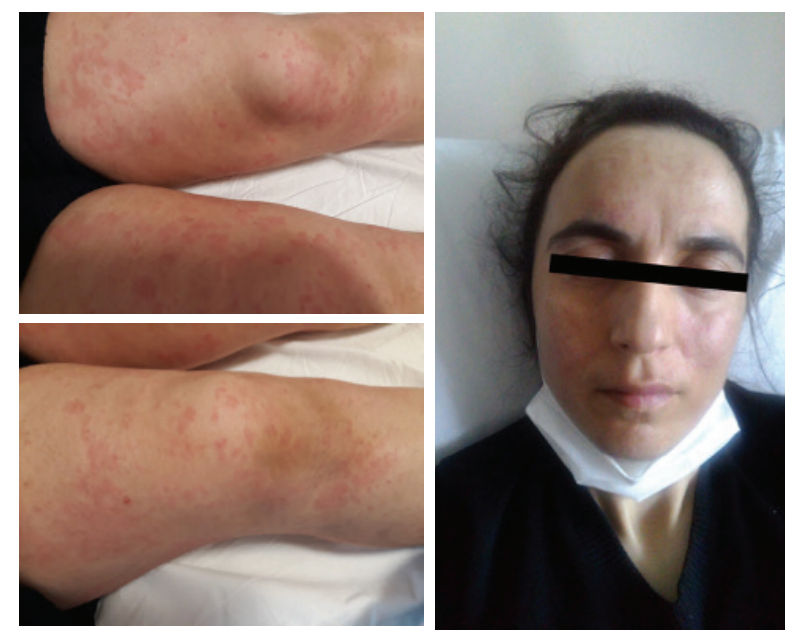

Resim1: Hastanın yüzünde ve alt ekstremitelerde yaygin yerleşimli, eritemli, keskin sınırl, birbirleriyle birleşme eğiliminde makül ve papüller lezyonlar

Merkezimizde orofarinks ve nasofarinksten alınan sürüntü örneğinin RT-PCR testi pozitif olarak saptandı. Çekilen Toraks Anjio Bilgisayarlı Tomografi incelemesinde pulmoner tromboembolizm tanısı dışlandı. Çekilen Toraks Bilgisayarlı Tomografisi incelemesinde sağ akciğer üst lob posterior ve orta lobda subplevral alanda şüpheli fokal buzlu cam tarzında dansite artımı saptandı ve bu bulgular COVID-19 için şüpheli bulgular olarak değerlendirildi.

Laboratuvar incelemelerinde; beyaz küre: 6,1 (4,60-10,20) K/uL, hemoglobin: 10,4 (12,20-18,10) g/dl, lenfosit: 1,43 
$(0,60-3,40) \mathrm{K} / \mathrm{uL}$ eosinofil: 0,001 $(0,0-0,7) \mathrm{K} / \mathrm{uL}$ trombosit : $217000 \mathrm{~K} / \mathrm{uL}, \mathrm{LDH}: 257$ (0-247) U/L , sodyum: 136 (136146) $\mathrm{mmol} / \mathrm{L}$, potasyum: $3,5(3,5-5,1) \mathrm{mmol} / \mathrm{L}$, kalsiyum: 9,4 (8,8-10,6) $\mathrm{mg} / \mathrm{dL}$, üre: 26 (17-43) $\mathrm{mg} / \mathrm{dL}$, kreatinin: 0,62 (0,67-1,17) mg/dL, D-dimer: 1220 (0-500) ugFEU/L, ferritin: $36 \mathrm{ug} / \mathrm{L}$, uluslararası standardize oran (INR):1,55 $(0,80-1,30)$, total $\lg -\mathrm{E}:<18,5(0-100) \mathrm{IU} / \mathrm{mL}$ saptand.

Hastanın döküntüleri ön planda ilaç erupsiyonu düşünülerek, mevcut tedavi de 5 günü doldurduğundan dolayı azitromisin, hidroksiklorokin ve enoksaparin sodyumdan oluşan tedavi sonlandırıldı. Döküntülerine yönelik tedavisine levosetirizin $10 \mathrm{mg} 1^{\star} 1$ po eklendi. İlaçlarının kesilmesine ve levosetirizin tedavisine rağmen hastanın döküntüleri ve kaşıntı şikayeti devam etti. Levosetirizin kesilip, feniramin $45.5 \mathrm{mg} / 2 \mathrm{ml}$ intravenöz (IV) $1^{\star} 1$ başlandı. Hastanın döküntü ve kaşıntı şikayetleri antihistaminik tedavisi başlandıktan 5 gün sonra ortadan kalktı. Hastanın döküntü ve kaşıntı şikayetlerinin geçmesiyle eş zamanlı alınan sürüntünün RT-PCR sonucu negatif saptandi.

Hastadan tıbbi verilerinin yayınlanabileceğine ilişkin yazilı onam belgesi alındı.

\section{TARTIŞMA}

Yapılan çalışmalarda COVID-19 hastalığının en sık görülen belirtileri arasında ateş yüksekliği, öksürük, nefes darlığının olduğu, bunun yanında bir çok farklı belirtiyle birlikte cilt bulgularının da olabildiği belirtilmiştir. ${ }^{4} \mathrm{Wu}-$ han'da yapılan 140 COVID-19 hastasının değerlendirildiği bir çalışmada; hastalarda döküntü görülme oranı $\% 1,4$ olarak bildirilmiştir. ${ }^{5}$ İtalya'dan yapılan bir bildiride son 15 gün içinde yeni bir ilaç kullananların dışlandığı COVID-19 tanısı olan 88 hastanın \%20.4 ünde (18 hasta) cilt bulguları olduğu bildirilmiştir. 14 hastada eritemli döküntü, 3’ünde yaygın ürtiker ve birinde ise suçiçeği benzeri veziküller görüldüğü bildirilmiştir. ${ }^{6}$ Tayland'dan yapılan bir bildiride peteşi ile başvuran hastanın trombosit sayısının düşük olduğu saptanınca bölgede yaygın görülen malaria hastalığı düşünülmüş, ancak sonradan hastada solunum problemlerinin ortaya çıkmasıyla yapılan RT-PCR sonucu COVID-19 hastalığı saptanması nedeniyle, hiç semptom yokken dahi peteşiyal döküntüsü olan hastalarda da COVID-19 hastalığı açısından dikkatli olunması gerektiği önerilmiştir. ${ }^{7}$

İspanya'da yapılan bir bildiride ise 84 yaşında kadın olguda COVID-19 hastalığı semptomları başladıktan 11 gün sonra fleksural bölgelerde kaşıntılı, eritemli milimetrik birleşme eğiliminde maküller gözlenmiş, almakta olduğu hidroksiklorokin, lopinavir/ritonavir tedavilerine mi viral enfeksiyona mı bağlı olduğunun ayrımının yapılamadığ bildirilmiştir. ${ }^{8}$

Çin'de ağır hastalık tablosu ile izlenen COVID-19 hastalığına sahip kişiler ile yapılan bir çalışmada akroiskemi göstergesi olan el ve ayak parmaklarında siyanoz, kuru kangren, büller ile ölüm arasında ortalama 12 gün hesaplanan, $\mathrm{D}$-dimer ve diğer hiperkoagulasyon testlerinin giderek kötüleştiği gözlenen 5 hasta bildirilmiştir. ${ }^{9}$

Olgumuzda COVID-19 hastalığına yönelik verilen tedavi sırasında başlayan, tedavinin kesilmesine rağmen devam eden döküntüler ilaç erupsiyonu ön tanısından kısmen uzaklaştırsa da lezyonlardan biyopsi örneği alınarak histopatolojik inceleme yapılamaması nedeniyle kesin ayırıcı tanı yapılamamıştır. Hastaya klinik olarak, viral enfeksiyonlarda ve bu hasta için hidroksiklorokin başta olmak üzere çoğu ilaçla birlikte ortaya çıkabilecek özgün olmayan makülopapüler erupsiyon tanısı konulmuştur. Olgumuz İspanya'dan bildirilen olgu ile klinik ve öykü açısından benzerlik göstermektedir. ${ }^{8}$

Yeni tanımlanmakta olan COVID-19'un klinik bulgular1nın anlaşılmaya çalışıldığı bu günlerde, hastalık sürecinde sonradan ortaya çıkan makülopapüler döküntü klinisyenler tarafından akılda tutulması gereken nadir bir bulgu olabilir. 
J Biotechnol and Strategic Health Res. 2020;4(2):173-177

\section{Maddi Destek ve Çıkar İlişkisi}

Çalışmayı maddi olarak destekleyen kişi/kuruluş yoktur

ve yazarların herhangi bir çıkar dayalı ilişkisi yoktur. 
J Biotechnol and Strategic Health Res. 2020;4(2):173-177

ETÇİOĞLU, AYDIN, DİKİCIER, Döküntünün Eşlik Ettiği SARS-CoV-2

\section{Kaynaklar}

1. Guo, Y, Cao, Q Hong Z. et al. The origin, transmission and clinical therapies on coronavirus disease 2019 (COVID-19) outbreak-an update on the status. Military Med Res. 2020;7:11.

2. Centers for Disease Control and Prevention. Symptoms of Coronavirus in Coronavirus Disease 2019 (COVID-19) https://www.cdc.gov/coronavirus/2019-ncov/symptoms-testing/symptoms.html?CDC_AA_refVal=https\%3A\%2F\%2Fwww.cdc.gov\%2Fcoronavirus\%2F2019-ncov\%2Fabout\%2Fsymptoms.html (Accessed on May 3, 2020)

3. World Health Organization. Clinical management of severe acute respiratory infection (SARI) when COVID-19 disease is suspected.2020. Available at: https://www.who.int/publications-detail/clinical-management-of-severe-acute-respiratory-infection-when-novel-coronavirus-(ncov)-infection-is-suspected. (Accessed May 2, 2020)

4. Guan WJ, Ni ZY, Hu Y, et al. Clinical characteristics of coronavirus disease 2019 in China. N Engl J Med. 2020;382:1708-1720.

5. Zhang JJ, Dong X, Cao YY, et al. Clinical characteristics of 140 patients infected with SARSCoV-2 in Wuhan, China. Allergy. 2020;00:1-12. doi: 10.1111/all.14238.
6. Recalcati S. Cutaneous manifestations in COVID-19: a first perspective. J Eur Acad Dermatol Venereol. 2020. doi: 10.1111/jdv.16387. [Epub ahead of print]

7. Joob B, Wiwanitkit V. COVID-19 can present with a rash and be mistaken for Dengue. J Am Acad Dermatol. 2020;82(5):e177. doi: 10.1016/j.jaad.2020.03.036.

8. Jimenez-Cauhe J, Ortega-Quijano D, Prieto-Barrios M, Moreno-Arrones OM, Fernandez-Nieto D. Re-ply to "COVID-19 can present with a rash and be mistaken for Dengue": Petechial rash in a patient with COVID-19 infection.J Am Acad Dermatol. 2020. doi: 10.1016/j.jaad.2020.04.016. [Epub ahead of print]

9. Zhang $Y$, Cao W, Xiao $M$, et al. Clinical and coagulation characteristics of 7 patients with critical COVID-2019 pneumonia and acro-ischemia. Zhonghua Xue Ye Xue Za Zhi. 2020;41(0):E006. doi: 10.3760/cma.j.issn.0253-2727.2020.0006. [Epub ahead of print] 